\title{
COVİD-19 SALGIN DÖNEMİNDE OTELLERİN PAZARLAMA STRATEJİLERI: KUŞADASI ÖRNEĞİ
}

Ahu YAZICI AYYILDIZ ${ }^{1}$

\author{
Received Date (Başvuru Tarihi): 1/08/2020 \\ Accepted Date (Kabul Tarihi): \\ $27 / 08 / 2020$ \\ Published Date (Yayın Tarihi):
}

$\ddot{O Z Z}$

\section{Anahtar Kelimeler:}

COVID-19,

Otel,

Pazarlama Stratejileri,

Kuşadası

JEL Kodları:

M30,

M31

COVID-19 küresel salgını tüm dünyayı etkisi altına alarak ülkelerin sosyoekonomik yapısnı durma noktasına getirmiş, turizm sektörü için de olumsuz sonuçlar doğurmuştur. Bu çalışmada COVID-19 salgınının turizm sektörüne ve otel işletmelerine etkileri incelenmiş, salgin sonrası yeniden faaliyete geçen otellerin, aldıklarn tedbirler ve uyguladiklar pazarlama stratejileri hakkında bilgiler elde edilmiştir. Bu amaç doğrultusunda Kuşadası'nda faaliyette bulunan 13 tane 5 yildızl otelin yöneticisiyle görüşmeler gerçekleştirilmiş, görüşmeler sonucu ortaya çıkan bulgular değerlendirilmiştir. Verilerin analizinde nitel araştırma tekniklerinden betimsel yöntem kullanılmıştır. Araştırma sonucunda otel işletmelerinin COVID-19 salginindan derinden etkilendikleri, oda fiyatlarının büyük oranda düştü̆g̈ü, seyahat kısıtlamaları nedeniyle kaybedilen pazarlar yerine farklı pazarlara yöneldikleri ortaya çıkmıştır. Satış-pazarlama faaliyetlerinin de alınan güvenlik önlemlerini vurgulayarak, buna yönelik olarak şekil değiştirdiği, sosyal medya reklamlarına ağırlık verildiği belirlenmiştir. Daha az temas gerektiren, QR kod okuyucular kullanılarak yapılan dijitalleşme uygulamalarına da yer verildiği ve gelecek yıllarda daha da fazla kullanılacağı dikkat çeken bulgular arasındadır.

$\begin{array}{llrrr}\text { Keywords: } & \text { COVID-19 } & \text { Hotel } & \text { Marketing Strategies } & \text { Kuşadası } \\ \text { JEL Codes: } & \text { M30 } & \text { M31 } & \end{array}$

\footnotetext{
${ }^{1}$ Dr. Öğr. Üyesi, Aydın Adnan Menderes Üniversitesi, Turizm Fak., ayazici@adu.edu.tr, https://orcid.org/0000-0002-1301-2428
}

Business \& Management Studies: An International Journal Vol.:8 Issue:3 Year:2020, 3328-3358 


\section{EXTENDED ABSTRACT}

\section{MARKETING STRATEGIES OF THE HOTELS IN COVID-19 PANDEMIC PROCESS: KUŞADASI SAMPLE}

\section{INTRODUCTION}

A COVID-19 global pandemic has brought the socio-economic structure of the countries to a halt by taking hold of all the world and has also created negative consequences for the tourism industry. By the measures taken within the scope of the COVID-19 pandemic, tourism-related expenditures have been on the top of the utmost reduced expenditures of the individuals due to the impact of social distance restrictions (McKinsey, 2020). Along with travel restrictions, flights, hotel reservations, events, and festivals have been cancelled, and this has significantly affected global tourism (Bahar \& Ilal, 2020). The pandemic has urged individuals and enterprises to become more conscious and sensitive in many issues. Hotel enterprises, which have begun to open doors again together with the measures they have taken after COVID-19, have also altered their marketing activities so that they emphasize the measures they have taken. Acar (2020) investigated the current and future effects of COVID-19 pandemic on the tourism sector; while Aydın and Doğan (2020) examined the changes in the decisions and behaviours of tourists together with the changes in the tourism sector after COVID-19. Bahar and İlal (2020) worked on the economic effects of COVID-19 pandemic on the tourism sector; Demir, Günaydin and Demir (2020) expressed that all the stakeholders of the sector should cooperate in the fight against COVID-19 pandemic; and Kivilcim (2020) stated that a new period would begin in the tourism sector after COVID-19 and contactless digital transactions, social distance tours and isolated holidays would be at the forefront.

Chang, McAleer and Ramos (2020) emphasized the importance of turning towards alternative tourism in their study on sustainable tourism after COVID-19. Gössling, Scott and Hall (2020) expressed in their study on the pandemic, tourism and global change that the pandemic has had a devastating effect on air travel and hospitality industry all over the world since March 2020; and Karim, Haque, Anis and Ulfy (2020) stated that hotels would have an enormous loss of income in Malaysia after COVID-19.

\section{THE PURPOSE AND IMPORTANCE OF THE RESEARCH}

The purpose of this study was to know the marketing strategies of the 5-star hotels operating in Kuşadası during the COVID-19 pandemic process. As a result of the literature review, it was revealed that there were no studies conducted addressing the marketing strategies applied by the hotels in Turkey in general or in Kuşadası specifically during COVID-19 pandemic process, which reveals the importance of the subject.

By the purpose of the study, the answers for the following questions were sought:

- Determining the measures taken by the 5-star hotel enterprises operating in Kuşadası for COVID-19 pandemic,

- Finding out the marketing strategies, advertising and promotion activities, of the 5-star hotel enterprises operating in Kuşadası during COVID-19 pandemic process,

- Determining the competition strategies of the hotels according to the changing consumer preferences during COVID-19 pandemic process.

\section{RESEARCH METHODOLOGY}

The qualitative research method was used within the scope of the study. Interviews were done with the hotel managers by making appointments in advance. While preparing the interview questions, the views of a faculty member who is an expert in the field and an experienced manager in the sector were obtained. Besides, the study by Demir et al. (2020) was also utilized. The population of the study was composed of the managers of the 5-star hotel enterprises operating in Kuşadasi. There are a total of 15 hotel enterprises operating in Kuşadası under Aydın Provincial Directorate of Culture and Tourism (Aydın Provincial Directorate of Culture and Tourism). The data of the research was 
obtained from 13 hotel managers between 10 July and 20 July 2020. The data could not be obtained from the two hotel enterprises because they did not open their doors for their guests this year because of COVID-19 pandemic. Descriptive analysis technique was used in order to analyze the data obtained in the research.

\section{RESEARCH FINDINGS}

Three of the managers interviewed within the scope of the study worked as a general manager, while 2 of them worked as an assistant manager, 4 of them worked as a front office manager, and 4 of them worked as a sales and marketing manager. It was found out that all of the hotels, except one, interviewed in the study had a safe tourism certificate, and the hotel without the relevant certificate did not have the certificate because they did not receive any supervision though they had applied before. It was emphasized that the certificate was essential in order for the guests to be able to rely on the hotel and for the hotel to be able to make its advertisement more effectively. Due to travel restrictions, the hotels operating in connection with the European and Far East markets (such as the Netherlands, Germany, Belgium, China) turned their faces to the domestic market and the markets such as Bulgaria and Ukraine, where the flights were not banned. After COVID-19, hotels verged intensely towards digital marketing, and thus, they began to use their social media accounts actively. Social media, which is one of the easiest and fastest means of transportation to reach huge masses, became prominent during the COVID-19 process compared to the other promotion tools. It was also stated that the prices of the hotels which began operating after COVID-19 decreased between $10 \%$ to $50 \%$. When the questions of "Are there any efforts you have made regarding digitalization after COVID-19?" and "If so, what are their effects on the promotion and marketing of your hotel?" were asked to the managers in the study, all the managers responded that the applications which required less contact come to the forefront in their hotels and that their importance was understood better after COVID-19. It was expressed that the applications such as accessing the menu with QR code readers, checking-in and checking-out with smartphone applications, and using the room service with the help of applications began to be preferred. The managers also stated that hygiene and safe accommodation were at the top of the expectations of the guests from the hotel after COVID-19. Furthermore, such holiday alternatives as preferring boutique hotels, renting villas, renting boats also became prominent after COVID-19. To the question of "What have you done for these competitive markets?", the managers responded that they had created new sales and marketing strategies such as $1+1,2+1,3+1$ suite flats to be rented daily and weekly which included a kitchen and all kinds of kitchenware as well, and farmhouses which were aimed at rural tourism.

\section{CONCLUSION AND SUGGESTIONS}

Tourism is one of the sectors that has mostly been affected by COVID-19 pandemic. With "Safe Tourism Certification Program" led by the Ministry of Culture and Tourism, hotels have made reorganizations. The fact that contactless transactions will increase and innovations regarding digitalization will be made in the hospitality sector after COVID-19 are of the important conclusions drawn from the interviews made with the managers within the scope of the study. The decrease in hotel accommodation prices in both the domestic and foreign market after COVID-19 caused a severe economic loss. This conclusion is in parallel with the result obtained in the studies by Acar (2020), Bahar and İlal (2020), Gössling, Scott and Hall (2020), Karim, Haque, Anis and Ulfy (2020) emphasizing that the tourism and hotel industry sector have suffered a massive loss in income.

The fact that the majority of the managers of the hotels, which opened their doors to guests after COVID-19, expressed they did not have very high expectations for 2020 but aimed to reach the end of the year with a low profit or without any financial loss is another conclusion drawn within the scope of the study. The conclusions that the governments are required to do the necessary planning for the recovery in tourism after COVID-19 pandemic, that the stakeholders of the industry are recommended to act collaboratively and come up with new projects, and that more effective and remarkable efforts are required to be made for advertisement and promotion are in parallel with the conclusions drawn in the studies by Atay (2020), Demir et al. (2020) and Gössling et al. (2020).

The recommendations to be made for hotel enterprises regarding the process after COVID-19 can be summarized as follows: 
-The criteria of hygiene and necessary measures, which are the main expectations of the guests, should be maintained, and great attention should be paid to this issue.

- Hotel enterprises should turn their faces towards the smart applications that require less contact. The importance of digitalization should be acknowledged better and budget should be allocated for this.

- It should be ensured that social media is used more actively.

- It should be ensured that the stakeholders of the sector come together in the promotion of the country and perform more effective promotional attacks. More effort should be made in order to create a more positive image in terms of health and safety in Turkey.

The fact that the current study, which aimed to investigate the marketing strategies of the hotels in COVID-19 pandemic process, was conducted in Kuşadası destination and only involved the 5 -star hotels are among the limitations of the study. A similar study can be conducted at different destinations. The satisfaction levels of the guests staying in hotels after COVID-19 can be measured by using quantitative and qualitative research methods. Interviews can be done with the other stakeholders in the sector, and information can be obtained regarding the marketing activities. 


\section{GİRIŞ}

COVID-19 salgını dünya genelinde turizm sektörünü derinden etkilemiştir. Koronavirüs, Çin'in Wuhan şehrinde 2019 yılı Aralık ayının sonlarında, deniz ürünlerinin satıldığı hayvan pazarında bulunan bir kişide görülen öksürük, ateş ve nefes darlığı belirtileriyle tespit edilen ve yapılan araştırmalar sonucu 13 Ocak 2020'de COVID-19 salgını adıyla tanımlanan bir virüstür (Sağlık Bakanlığı, 2020). Dünya Sağlık Örgütü tarafından COVID-19 salgını, 30 Ocak 2020 tarihinde uluslararası kamu sağlığı acil durumu, 11 Mart 2020 tarihinde ise pandemi (evrensel salgın hastalık) olarak ilan edilmiştir (Who, 2020). Türkiye'de ilk vaka 10 Mart 2020 'de görülmüştür. Dünya sağlık örgütü verilerine göre dünya genelinde bugüne kadar (20.07.2020) koronavirüs görülen 14.194 .796 vaka ve virüs dolayısıyla ölen 599.438 kişi bulunmaktadır. Türkiye'de ise, 217.799 vaka ve 5.458 ölüm gerçekleşmiştir (Worldometer, 2020).

COVID-19 salgını kapsamında alınan tedbirler doğrultusunda sosyal mesafe kısıtlamalarının etkisiyle bireylerin en çok düşürdükleri harcamaların başında turizmle ilgili harcamalar gelmektedir (McKinsey, 2020). Nisan 2020 itibarıyla, tüm dünya destinasyonlarının \%96'sı COVID-19 salgınını önlemeye yönelik seyahat kısıtlamaları uygulamıştır. Seyahat kısıtlamaları ile birlikte uçuşlar, otel rezervasyonları, etkinlikler, festivaller iptal edilmiş ve bu durum küresel turizmi oldukça etkilemiştir (Bahar ve İlal, 2020). Şanlı, Erdem ve Unur (2020) çalışmalarında, tüketicilerin büyük bir çoğunluğunun koronavirüs salgınından önce tatile çıkma niyetine sahipken, koronavirüs nedeniyle tatile çıkma düşüncelerinde değişiklik meydana geldiğini, ayrıca koronavirüs salgınının katılımcıların neredeyse yarısının tatil yeri tercihinin değişmesinde etkili olduğunu belirtmişlerdir (Şanll, Erdem ve Unur, 2020). Başka bir çalışmada tüketicilere seyahat acentelerinin tur teklifleri ile ilgilenip ilgilenmedikleri sorulmuş ve katılımcılar genellikle turlarla ilgilenmediklerini ya da gelecek yıl ilgileneceklerini ifade eden cevaplar vermişlerdir (Ekstein, 2020). Salgın sonrası en büyük değişikliğe otellerin maruz kalacağı, bunun temel nedeninin ise, salgının otel işletmelerinde alınacak tedbirlerle birlikte yüksek maliyetlere yol açacak olmasıdır (Özdemir, 2020:232). COVID-19 salgınının ortaya çıkardığı olumsuzluklar turizm ürünü ve hizmet sunumlarının artık salgın öncesi 
gibi olmayacağını göstermiştir. Tatil yapacak turistlerin otel tercihlerinde daha seçici, sağlık koşullarına daha dikkat edici davranışlar içinde olması beklenmektedir (Demir ve Türkmen, 2020).

Bu çalışma kapsamında öncelikle COVID-19 salgınının dünyada ve Türkiye' de turizm sektörüne etkileri üzerinde durulmuş, salgının otel işletmelerinin pazarlama stratejilerine etkilerinden bahsedilmiş ve son olarak da otel yöneticileri ile yapılan görüşmelerde elde edilen bulgular neticesinde Kuşadası'nda faaliyette bulunan 5 yıldızlı otellerin COVID-19 salgın döneminde uyguladıkları pazarlama stratejileri araştırılarak bilgi verilmiştir.

\section{KONU İLE İLGİLI YAPILMIŞ ÇALIŞMALAR}

Acar (2020), COVİD-19 salgının turizm sektörü üzerindeki mevcut ve ilerleyen zamanlardaki olası etkilerini araştırmış, virüsün uzun yıllar hissedilecek olumsuz etkileri olduğunu, turizm sektörünün de bu olumsuzluklardan etkileneceğini vurgulamıştır.

Atay (2020), COVİD-19 salgını ve turizme etkileri ile ilgili yaptığ1 çalışmasında, salgın sonrası sürecin kamu ve özel sektör tarafından çok iyi yönetilmesi gerektiğini, vize ve benzeri seyahat engellerinin en aza indirilmesi, seyahat imkanlarının kolaylaştırılması ve Türkiye'ye yönelik seyahatin teşvik edilmesine yönelik adımların atılmasının önemini belirtmiştir.

Aydın ve Doğan (2020), COVİD-19 sonrası turizm sektöründeki değişimlerle birlikte, turistlerin karar ve davranışlarındaki değişiklikleri inceleyip, turistlerin kitle turizmi yerine kamp, karavan, sezonluk konut kiralama, yat kiralama gibi tatil türleri tercih edeceğini belirtmişlerdir.

Bahar ve İlal (2020), COVİD-19 salgınının turizm sektörü üzerindeki ekonomik etkilerini incelemiş, salgının ortaya çıkaracağı talep şoklarının turizm sektöründe gelir kayıplarına yol açacağını ifade etmiştir. 
Demir, Günaydın ve Demir (2020), otel, havayolu, yat ve tekne işletmeleri, tur operatörleri ve seyahat acentalarının üst düzey yöneticileri/sahipleriyle görüşme yaparak COVID-19 salgınının Türkiye'de turizm sektörü üzerindeki etkilerini incelemişlerdir. Çalışmada COVİD-19 salgını ile mücadelede tüm sektör paydaşlarının iş birliği yapması gerektiği vurgulanarak, kalabalık turizm tesisleri, ulaştırma araçları, restoran ve eğlence yerleri, tur programları ve transferler yerine kişiye özel hizmetlerin sunulduğu, daha küçük tesislerin ve daha küçük grup tatil ve seyahat hizmetlerinin tercih edileceğini öngörmektedirler.

Demir ve Türkmen (2020), COVID-19 salgını sonrasında Türk turistlerin tatil yapmaya yönelik bakış açıları ve beklentilerini ortaya çıkartmak amacıyla yaptıkları çalışmalarında turistlerin önemli bir kısmının seyahat yasaklarının kalkması durumunda Temmuz-Ekim dönemi içerisinde butik otellerde tatil yapmayı düşündükleri ortaya çıkmıştır. Turizm işletmelerinin temizlik ve sosyal mesafenin sağlanması hususunda tedbir alması gerektiği belirtilmiştir.

Doğanc1lı (2020), COVİD-19 salgını sonrasında Türkiye'deki turizm sektöründe ki destek uygulamalarını ortaya koymak amacıyla yaptığı çalışmasında ilgili kurumların sertifika programları, teşvik unsurları ve iş esnasında uyması gereken kuralları incelemiş; en kapsamlı düzenlemelerin konaklama sektöründe yapıldığını belirtmiştir. Çalışmada Kültür ve Turizm Bakanlığı'nca düzenlenen "Sağlıklı Turizm Sertifika Programı" ile birçok departmana ilişkin hijyen kuralları sağlandığı fakat seyahat acentaları, profesyonel turist rehberleri ve ulaştırma sektöründe yeterli düzenlemelerin olmadığ1 vurgulanmıştır.

Eryılmaz (2020), Türkiye'de bulunan yerli ve uluslararası zincir otellerin web sitelerinde COVID-19 ile ilgili yaptıkları bilgilendirmeleri ele alarak uluslararası zincir otellerin müşterilerine; rezervasyon iptal ve değişiklik bilgileri, hijyen uygulamaları ve sadakat programlarına üye müşterinin durumu gibi konularda daha detaylı bilgi paylaştığı sonucuna varmıştır.

İbiş (2020), COVİ-19 salgınının Türkiye'deki seyahat acentalarını nasıl etkilediğini ortaya çıkarmak için İstanbul'da faaliyette bulunan 11 seyahat acentası yetkilisi ile görüşmeler yapmıştır. Çalışmada seyahat acentalarının COVID-19 
salgınından büyük ölçüde etkilendikleri, gelir kaynaklarının kesildiği belirtilmiştir. Buna rağmen birçok sabit giderlerinin devam ettiği, acentaların daha fazla desteğe ihtiyaç duydukları ortaya çıkmıştır.

Kıvılcım (2020), COVİD-19 salgınının turizm sektörüne etkilerini ele aldığ1 çalışmasında, COVID-19 sonrası turizm sektöründe yeni bir dönemin başlayacağını, temassız dijital işlemler, sosyal mesafeli turlar ve izole tatillerin ön planda olacağını belirtmiştir.

Tanrıkılu (2020), COVİ-19 gölgesinde Türkiye'de holistik turizm konusunda çalışma yaparak, Türkiye' nin klasikleşmiş turizm anlayışı yerine, turizmde kültüre dönüşle birlikte tarih, kültür, sanat, kongre, gastronomi, müzik, sağllk, spor, mutfak, kış turizmi ve benzerlerinin içinde bulunduğu holistik turizme yönelmesi gerektiğini vurgulamıştır.

Yenişehirlioğlu ve Salha (2020), COVİD-19 pandemisinin Türkiye'nin iç turizmine etkileri üzerine bir araştırma yapmışlardır. Araştırmanın sonucunda; yerel turistlerin 2020 yılının yaz aylarında tatil yapmak istemediklerini, tatil yapacak kişilerin ise mümkünse insanların çok az, sosyal mesafenin yüksek olduğu yazlık, bungalow, yayla gibi seçenekleri değerlendirecekleri tespit edilmiştir.

Şanlı C., Erdem ve Unur (2020), bireylerin koronavirüs salgınına yönelik algılarının, koronavirüse ilişkin önlemlerinin ve koronavirüse yönelik ilgilerinin tatil satın alma niyeti ile ilişkisini incelemişlerdir. Araştırma sonucuna göre katılımcıların büyük bir çoğunluğu koronavirüs salgınından önce tatile çıkma niyetine sahipken, koronavirüs nedeniyle tatile çıkma düşüncelerinde değişiklik meydana geldiği ortaya çıkmıştır.

Bakar ve Rosbi (2020), COVID-19'un turizm endüstrisine etkisi üzerine yaptıkları çalışmalarında arz-talep teorisinin piyasa dengesine göre turizm sektörünün fiyatının talepteki düşüşe paralel olarak düşmeye devam edeceğini, turizm endüstrisinde azalan talebin önlenmesi ve durdurulması için hükümetlerin önleyici bir mekanizma geliştirmesi gerektiğini ifade etmişlerdir. Buna ek olarak hükümetlerin önleme eyleminin olmaması durumunda, turizm endüstrisinin ekonomik çöküşe maruz kalacağını belirtmişlerdir. 
Chang, McAleer ve Ramos (2020), COVİD-19 sonrası sürdürülebilir turizmle ilgili yaptıkları çalışmada turistin çıkış noktasından varış noktasına kadar destinasyonlarda sosyal mesafenin korunması gerektiğini, yolculuk esnasında kişisel koruma ekipmanı kullanılmasının önemini belirterek, din turizmi, macera turizmi, çiftlik turizmi, kongre turizmine yönelmek gerektiğini, otellerde giriş ve çıkış işlemleri yapılırken, yemek servisi ve sosyal faaliyetler esnasında sosyal mesafenin korunmasının önemini vurgulamışlardır.

Gössling, Scott ve Hall (2020), pandemi, turizm ve küresel değişim konulu çalışmalarında dünyada Mart 2020'den bu yana salgının hava yolculuğu ve konaklama sektörü üzerinde yıkıcı bir etkiye sebep olduğunu belirtmiştir. Sürdürülebilir turizmin dönüşümünü hızlandırmak için bu küresel trajediye meydan okumanın öğrenilmesi gerektiğini vurgulamışlardır.

Hoque, Shikha, Hasanat, Arif ve Abdul Hamid (2020), COVID-19 salgınının Çin'in turizm endüstrisini nasıl etkilediği üzerine çalışma yapmışlardır. Sonuç olarak virüs nedeniyle Çin dışında yaşayan insanların Çin'de yaşayan insanlarla bir araya gelmekten korktukları, turistlerin Çin'i ziyaret etme planlarını iptal ettikleri ortaya çıkmıştır.

Karim, Haque, Anis ve Ulfy (2020), COVİD-19 krizinin Malezya' da turizm ve konaklama sektörü üzerindeki etkilerini incelemişlerdir. Çalışma sonuçlarına göre, COVID-19 sonrasında tüm havayolu şirketlerinin Malezya'ya ve Malezya'dan uçuşları durdurduğunu, konaklama sektörünün de çok zor bir dönemden geçtiğini ifade etmişler, otellerin bu dönemde çok büyük bir gelir kaybı olacağını belirtmişlerdir.

Khadka, Pokhrel, Thakur, Magar, Bhatta, Dhamala ve Bhuju (2020), COVID19'un Nepal'de turizm endüstrisi üzerindeki etkilerini incelemiş, özellikle Nepal'e, Çin, Hindistan ve ABD'den gelen turist sayısının yıllık akışının bir milyondan fazla olduğunu fakat Mart ayından bu yana bu rakamın çok düştüğünü belirtmişlerdir. Nepal turizminin daha fazla kayıp yaşamaması için uzmanlardan oluşan turizm sektörü paydaşlarının stratejik bir plan hazırlaması gerektiğini ifade etmişlerdir. 
Ranasinghe, Damunupola, Wijesundara, Karunarathna, Nawarathna, Gamage, Ranaweera ve Idroos (2020), Sri Lanka' da COVID-19 sonrası turizm, otel ve Mice endüstrisinin ilerlemesi hakkında bir çalışma yapmışlar, esnek fiyatlar, iptal politikaları, esnek çalışma ortamı gibi kolaylıkların otelcilik endüstrisinin uzun vadeli sürdürülebilirliğini sağlamada faydalı olacağını ifade etmişlerdir. Aynı zamanda iş kayıplarını gidermek ve misafirlerin zihninde olumlu imajı yeniden oluşturmak için hem yerel hem de uluslararası pazarlama ve tanıtım kampanyaları başlatmanın önemine de değinmişlerdir.

Sheresheva, (2020), Rus turizm endüstrisinin COVID-19'dan genel olarak nasil etkilendiğine ilişkin yaptığı çalışmasında iç turizmin desteklenmesinin ekonomik toparlanma açısından önemine değinmiştir.

Wen, Kozak, Yang ve Liu (2020), COVİD-19 salgınının Çinli turistlerin yaşam tarzı seçimlerini, seyahat davranışlarını ve turizm tercihlerini kısa ve uzun vadede nasıl değiştirebileceğini incelemişlerdir. COVİD-19'un, Çinli gezginlerin bağımsız seyahatlerin artan popülaritesini, lüks gezileri ve sağlıklı yaşam turizmi gibi tüketim modellerini etkileyeceğini öngörmektedirler. Yavaş turizm ve ak1llı turizm de dahil olmak üzere yeni turizm biçimlerinin gelecekteki turizm faaliyetlerini yönlendireceğini, bu tür değişikliklerin, işletmelerin hizmet tasarımlarını ve dağıtım kanallarını önemini ortaya çıkartacağını belirtmişlerdir.

Wilson ve Chen (2020), yapılan seyahatlerin COVID-19'un yayılmasina etkilerinden bahsetmiş, Çin'in Wuhan kentinden diğer ülkere yapılan seyahatlerin virüsün dağılmasında etkili bir rol üstlendiğini belirtmiştir.

\section{COVİD-19 SALGINI VE TURIZZME ETKİLERİ}

Turizm çok hassas ve çevresinde gelişen olumsuz faktörlerden çok çabuk etkilenen bir sektördür. İnsan sağlı̆̆1 ya da güvenliği ile ilgili hafif bir risk bile; doğal afetler, terör olayları, salgın hastalıklar gibi, turistik bir bölgenin tercih edilmemesi için yeterlidir (Lee ve Chen, 2011). Ülkelerin turizm faaliyetleri ile salgın hastalıklar arasında negatif yönlü bir ilişki bulunmaktadır (Karim vd., 2020). Bundan dolayı tüm dünyada ve Türkiye'de COVID-19 salgını turizm sektörünü olumsuz yönde etkilemiştir. Salgını önlemeye yönelik tüm dünyada destinasyonların \%96'sı Nisan 
2020 itibarıyla seyahat etmeyi kısıtlayan tedbirler uygulamışlardır. Seyahat kısıtlamaları uçuşların ve otel rezervasyonlarının iptal edilmesine neden olmuştur. Ayrıca alınan tedbirler çerçevesinde cafe, restoran, müze ve ören yerlerinin faaliyetlerine ara verilmesi, toplantı, kongre, festival gibi etkinliklerin durdurulması sektörü derinden etkilemiştir (Bahar ve İlal, 2020).

Son üç yılın verilerine göre Türkiye 2019 yılında ülkelere göre gelen turist sayısına göre dünyada 6. sırada yer almıştır (Tablo 1.) Avrupa'da 2019 yılında ülkelere göre gelen turist sayısına göre de Fransa, İspanya ve İtalya'dan sonra 4. Sirada yer almıştır.

Tablo 1. Ülkelere Göre Gelen Turist Sayısı (Dünya Sıralaması-Milyon Kişi)

\begin{tabular}{|c|c|c|c|c|}
\hline Siralama & Ülkeler & 2019 & 2018 & 2017 \\
\hline 1 & Fransa & - & 89.4 & 86.9 \\
\hline 2 & İspanya & 83.7 & 82.8 & 81.9 \\
\hline 3 & $\mathrm{ABD}$ & 79.3 & 79.7 & 76.9 \\
\hline 4 & Çin & 65.7 & 62.9 & 60.7 \\
\hline 5 & İtalya & 64.5 & 61.6 & 58.3 \\
\hline 6 & Türkiye & 51.2 & 45.8 & 37.6 \\
\hline 7 & Meksika & 45.0 & 41.3 & 39.3 \\
\hline 8 & Tayland & 39.8 & 38.2 & 35.6 \\
\hline 9 & Almanya & 39.6 & 38.9 & 37.5 \\
\hline 10 & İngiltere & - & 36.3 & 37.7 \\
\hline
\end{tabular}

2019 yılında dünyada 1,5 milyar kişi turizm faaliyetlerine katılmıştır. Dünya Turizm Örgütü'nün verilerine göre, küresel seyahat endüstrisi 2020 y1lının ilk çeyreğinde \%22 azalma göstermiştir. 2020 yılındaki uluslararası turist hareketliliğinin \%20 ile \%30 arasında bir oranda azalma göstereceği, yaklaşık 300 ile 450 milyar dolar arasında kayba uğrayacağı tahmin edilmektedir (UNWTO, 2020). STR Global (Smith Travel Research) verilerine göre, normal şartlarda doluluk oranı \%70 ile 100 arasında seyreden dünyanın en büyük şehirlerindeki otellerin doluluk oranları, Mart ayında \%20'lere düşmüştür. Otellerin doluluk oranlarındaki en fazla düşüş İtalya'da yaşanırken, ikinci sırada Çin ve üçüncü sırada Yunanistan'da gerçekleşmiştir (https://str.com). Türkiye Otelciler Birliği (TÜROB) araştırmasına göre, Avrupa'da Mart 2020'de otellerde doluluk oranları \%26,3'lük ortalama ile 2. Dünya Savaşı'ndan bu yana en düşük seviyeyi görmüştür. Geçen yılın mart ayında Avrupa doluluk ortalaması \%68,5 iken, Mart 2020'de Avrupa'da doluluklar geçen 
yılın aynı ayına göre \%61,6 geriledi. Avrupa ülkeleri arasında mart ayı içerisinde, doluluk oranlarında, en büyük düşüş oranı \%90,8 ile İtalya' da yaşanmıştır. İtalya'nın Mart 2020' de doluluk oranı \%6,2 olmuştur (TÜROB).

Kültür ve Turizm Bakanlı̆̆ı verilerine göre; Türkiye 2019'da 45,1 milyon yabancı ziyaretçi ağırladı. Turizm geliri 34,5 milyar dolar oldu ve bu rakamın \%83'ü yabancı ziyaretçiden elde edildi. 2020 yılı Ocak ayında ziyaretçi sayısı bir önceki yıla oranla \%16,11 artarken, 2020 Şubat ayında ise, bir önceki yıla göre ziyaretçi sayısı \%3,76 oranında artmıştır. Türkiye'ye 2019 yılında en çok ziyaretçi gönderen ülke Rusya olurken, ikinci sırada Almanya, üçüncü sırada ise İngiltere olmuştur. COVİD19 vakalarının Türkiye' de görülmeye başlandığı Mart ayında ise, Türkiye'yi ziyaret eden yabancı sayısı bir önceki yılın aynı ayına göre \%67,83 azalış göstermiştir. Nisan ve Mayıs aylarında ise, bir önceki yıla göre \%99,26'lık bir azalış kaydedilmiştir. Ocak-Mart 2020 döneminde geçen yıla göre \%11,4 azalışla 4,1 milyar dolar turizm geliri elde edilmiştir. Bu dönemde en çok turist 1,7 milyon ile Almanya'dan, ikinci sırada, 1,2 milyon ile Rusya'dan, üçüncü sırada ise, 329 bin ile İngiltere' den gelmiştir ( www.yigm.ktb.gov.tr). Sonrasında tüm dünyada uygulanan seyahat engelleri ile yabancı turistlerin ülkeye gelişi kısıtlanmıştır. Bu rakamlar COVID-19 salgının Türkiye'de turizmi ne derecede etkilediğini göstermektedir.

2019 yılında Türkiye' de konaklama tesislerinde, tesise geliş sayısı bir önceki yıla göre \%12,38 artış göstererek 80,87 milyon'a, geceleme sayısı ise bir önceki yıla göre \%10,8 artarak 211,29 milyon'a ulaşmıştır. 2019 yılında ortalama kalış süresi 2,61gün, doluluk oranı ise \%53,48 olarak gerçekleşmiştir. Y1l içerisinde en yüksek doluluk oranına 2019 yılında \%77,48 ile Ağustos ayında ulaşılmıştır (www.yigm.ktb.gov.tr). STR'nin hazırladı̆̆ı Ocak 2020 Destinasyon Performans Raporu'na göre, Türkiye'nin Ocak 2020 otel dolulukları, geçen yılın aynı dönemine göre \%6,4 artarak \%61,9 olarak gerçekleşmiştir. Bu durum Türkiye'de henüz COVID19 vakaları görülmeden önce 2020 yılı otel doluluk beklentilerinin yüksek seviyede olduğunu göstermektedir. Verilere göre, 2020 yılının 3 aylık döneminde tesise geliş 7,7 milyon kişi, geceleme sayısı da 16,2 milyon olarak gerçekleşmiştir. Bir önceki yılın ilk 3 aylık dönemine göre 2020'de tesislere gelişler \%12, geceleme sayısı ise, \%12,9 azalmıştır. Doluluk oranı da 2019'un ilk üç ayında \%37,68 iken, 2020 yılının ilk üç 
aylık döneminde \%30,94 olmuştur. Türkiye'nin Mart 2020 otel dolulukları, 2019 yılının aynı dönemine oranla \%55,2 azalarak, \%28,6 olarak kaydedilmiştir. Mart 2019'da bu oran \%63,8 olmuştur (STR) COVİD-19 vakaları Türkiye'de görülmeye başladıktan sonra, salgın nedeniyle uygulanan seyahat yasakları, sınır kapılarının kapatılması gibi kısıtlamalar ilk üç ayda otellerin doluluk oranlarının düşmesine sebep olmuştur. 23 Nisan, 19 Mayıs ve Ramazan Bayramı tatillerinde uygulanan dörder günlük sokağa çıkma yasakları ile 31 ilde uygulanan giriş-çıkış kısıtlamaları iç turizmi de olumsuz yönde etkilemiştir. Aydın ili genelinde 2019 yılında gerçekleşen konaklama tesislerinin toplam doluluk oranları \%59,94'dür. 2020 yılı Mayıs ayında Aydın ili genelinde konaklama tesislerinin doluluk oranları \%1,10 olarak kayıtlara geçerken, Kuşadası ilçesinde bu rakam \%5,46'dır (www.yigm.ktb.gov.tr/tesis-konaklama-istatistikleri).

\section{COVID-19 SALGINI VE OTEL IŞLETMELERININ PAZARLAMA}

\section{STRATEJİLERİ}

Otel işletmelerinin pazarlama stratejilerini oluştururken kendilerine özel strateji geliştirmeleri gerekmektedir. Bunu yaparken de dikkat etmeleri gereken bazı hususlar vardır. Bunlar; pazardaki rekabetçi ortama dikkat ederek strateji geliştirme, pazarda oluşabilecek değişikliklere karşı hazırlıklı olma, çevresel faktörlere ayak uydurma, tüketicinin değişen tercihlerine uygun ürün ve hizmet sunmadır (Dasgupta, 2011). Otel işletmelerinin pazarlama stratejilerinin temelinde misafiri memnun etmek ve misafir sadakati sağlamak vardır. Bunun içinde misafirle etkili iletişim kurma ve ilişkisel pazarlamaya yönelme önemlidir. Ayrıca günümüzde sosyal medya, otel işletmelerinin hedef kitlelerine ve misafirlerine ulaşmaları açısından çok etkilidir. Oteller; reklam, tanıtım, satış promosyonları, halkla ilişkiler gibi faaliyetleri sosyal medya araçlarını kullanarak kolaylıkla gerçekleştirebilmektedirler.

Tüm dünyayı etkileyen COVİD-19 salgını, bireyleri ve işletmeleri birçok konuda daha bilinçli ve hassas olmaya teşvik etmiştir. Türkiye' de faaliyet gösteren otel işletmeleri için T.C Sağlık Bakanlığı tarafından 21.04.2020 tarihinde alınan kararlara göre temel enfeksiyondan korunma ve kontrol ilkelerinin uygulanması 
önerilmiştir. Bu ilkeler; "genel temizlik kuralları", "konaklama tesislerinde konaklayanlar arasında COVID-19 hastalığı ile uyumlu şikâyetleri (ateşe eşlik eden öksürük veya solunum sıkıntısı) olan kişiler olması durumunda yapılacaklar" ve "otel çalışanlarına eğitim verilecek konular" şeklinde 3 başlık altında toplam 20 maddeden oluşmaktadır (Eryılmaz, 2020:17).

Ayrıca dünyadaki ilk örneklerinden olan "Güvenli Turizm Sertifikasyon Programı", Kültür ve Turizm Bakanlığı'nın öncülüğünde, Sağlık, Ulaştırma, İçişleri ve Dışişleri Bakanlıklarının katkıları ve tüm sektör paydaşlarının iş birliğiyle hazırlanıp, tatilini Türkiye'de geçirecek tüm Türk vatandaşlara ve yabancı ziyaretçilere ulaşımdan konaklamaya, tesis çalışanlarından yolcuların kendi sağlık durumuna uzanan bir yelpazede alınması önerilen tedbirleri içermektedir. Değerlendirme formunda yer alan kriter başlıkları arasında; otellerin uygulaması gereken zorunlu uygulamalar, misafirin otele girişi ile ilgili uygulamalar, personel için alınacak önlem ve uygulamalar, genel alanlarda düzenlemeler (yatak odaları, mutfaklar, yeme-içme üniteleri, yüzme havuzları ve plajlar, fitness salonları-spa, animasyon salonları, mini kulüp), otel güvenliği ile ilgili düzenlemeler, otel taşıtları ile ilgili uygulanacaklar, personel konaklama üniteleri ve lojmanlar ile ilgili düzenlemeler, atık yönetimi, haşere ve zararlılarla mücadele, satın alma, mal kabulü ve depolama ile ilgili uygulanacaklar, acil durum ve izolasyon düzenlemeleri yer almaktadır (Türkiye Turizm Tanıtım ve Geliştirme Ajansı).

Güvenli Turizm Sertifikası alan işletmeler, Kültür ve Turizm Bakanlığı web sitesinde duyurulmaktadır. Güvenli turizm Sertifikası logosu, belgeyi alan işletmelerin tüm misafir ve çalışanlar tarafından görülebilen alanlarına asılarak ve misafirlerin belge üzerindeki kare kodu okutmasıyla, tesis ile ilgili tüm denetleme bilgilerine ulaşabilmelerini sağlamaktadır. Böylelikle otel işletmeleri misafirlerine karşı güven ortamı yaratarak, belgeyi satış pazarlama faaliyetlerinde de kullanabilmektedirler.

\section{ARAŞTIRMANIN AMACI VE ÖNEMİ}

Bu çalışmanın amacı COVİD-19 salgın döneminde Kuşadası'nda faaliyette bulunan 5 yıldızlı otellerin pazarlama stratejilerinin belirlenmesidir. Yapılan literatür 
taraması sonucunda Türkiye genelinde ve Kuşadası'nda COVİ-19 salgın döneminde otellerin uyguladıkları pazarlama stratejilerini ele alan herhangi bir çalışmaya rastlanmamış olması konunun önemini ortaya koymaktadır.

Çalışmanın amacı doğrultusunda şu sorulara cevap aranmaktadır:

-Kuşadası'nda faaliyette bulunan 5 yıldızlı otel işletmelerinin COVID-19 salgını için otellerde aldıkları tedbirler nelerdir?

-Kuşadası' nda faaliyette bulunan 5 yıldızlı otel işletmelerinin COVID-19 salgın döneminde uyguladıkları pazarlama stratejileri, reklam ve tanıtım çalışmaları nelerdir?

-COVID-19 salgın döneminde değişen tüketici tercihlerine göre otellerin rekabet stratejileri nelerdir?

\section{ARAŞTIRMANIN YÖNTEMI}

Çalışma kapsamında nitel araştırma yöntemi kullanılmıştır. Nitel araştırmalar, olayların ve algıların doğal ortamında bütüncül ve gerçekçi bir biçimde ortaya konulmasına yönelik nitel bir sürecin izlendiği, araştırmacıya esneklik sağlayan ve derinlemesine bilgi toplama imkânı veren araştırma olarak tanımlanmaktadır (Yıldırım ve Şimşek, 2016). Görüşmeler yarı yapılandırılmış mülakat tekniği kullanılarak gerçekleştirilmiştir. Yarı yapılandırılmış mülakat; araştırmacıların genel bir çerçeveye sahip olduğu, ancak mülakatın gidişatına göre farklı soruların üretilerek, detaylı ve farklı boyutlarda verilerin alınmaya çalışıldığı bir veri toplama tekniğidir (Altunışık, Coşkun, Bayraktaroğlu ve Yıldırım, 2010).

Çalışma doğrultusunda, önceden randevu alınarak otel yöneticileriyle görüşmeler yapılmıştır. Görüşme esnasında alınan cevaplar yazılı olarak kayıt edilmiştir. Görüşme soruları hazırlanırken alanında uzman bir öğretim üyesi ve sektörde tecrübeli bir yöneticinin görüşleri alınmıştır. Ayrıca Demir vd., (2020)'nin çalışmasından yararlanılmıştır. Çalışma evrenini Kuşadası'nda faaliyette bulunan 5 yıldızlı otel işletmelerinin yöneticileri oluşturmaktadır. Aydın İl Kültür ve Turizm Müdürlüğü'ne bağlı Kuşadası'nda faaliyette bulunan toplam 15 tane otel işletmesi vardır (Aydın İl Kültür ve Turizm Müdürlüğü). Araştırma verileri Adnan Menderes 
Üniversitesi Sosyal ve Beşerî Bilimler Araştırmaları Etik Kurulu'nca 22.07.2020 tarihinde 31906847/050.04.04-08/15 sayılı kararı ile alınan etik kurul onayı ile 13 otel yöneticisinden 23 Temmuz-30 Temmuz 2020 tarihleri arasında toplanmıştır. İki otel işletmesi COVID-19'dan dolayı bu sene açılmadığı için bilgi toplanamamıştır. Araştırmada elde edilen verilerin analizinde betimsel analiz tekniği kullanılmıştır. Betimsel analiz, elde edilen bulguların doğrudan aktarılması ve katılımcı görüşlerinin sentezlenerek çeşitli çıkarımlarda bulunulmasıdır (Gürbüz ve Şahin, 2014).

\section{ARAŞTIRMA BULGULARI}

Görüşme yapılan katılımcılara ait yaş, cinsiyet, eğitim durumu, çalıştıkları oteldeki pozisyonları ve iş tecrübelerine ait bilgiler Tablo 2'de verilmiştir.

Tablo 2. Katılımcılara İlişkin Genel Bilgiler

\begin{tabular}{|c|c|c|c|c|c|}
\hline Katılımcı & Yaş & Cinsiyet & $\begin{array}{c}\text { Eğitim } \\
\text { Durumu }\end{array}$ & Pozisyon & İş Tecrübesi \\
\hline $\mathbf{1}$ & 40 & Erkek & Lisans & Genel Müdür & 23 yıl \\
\hline $\mathbf{2}$ & 39 & Erkek & Lisans & Genel Müdür & 15 yıl \\
\hline $\mathbf{3}$ & 41 & Erkek & Lisans & Önbüro Müdürü & 22 yıl \\
\hline $\mathbf{4}$ & 45 & Erkek & Ön Lisans & Önbüro Müdürü & 23 yıl \\
\hline $\mathbf{5}$ & 38 & Erkek & Lisans & $\begin{array}{c}\text { Satış-Pazarlama } \\
\text { Müdürü }\end{array}$ & 19 yıl \\
\hline $\mathbf{6}$ & 42 & Erkek & Lisans & $\begin{array}{c}\text { Genel Müdür } \\
\text { Yardımcısı }\end{array}$ & 22 yıl \\
\hline $\mathbf{7}$ & 45 & Kadın & Lisans & $\begin{array}{c}\text { Önbüro Müdürü } \\
21 \text { yıl }\end{array}$ \\
\hline $\mathbf{8}$ & 40 & Erkek & Lisans & $\begin{array}{c}\text { Satıs-Pazarlama } \\
\text { Müdürü }\end{array}$ & 19 yıl \\
\hline $\mathbf{9}$ & 43 & Erkek & Lisans & Genel Müdür & 24 yıl \\
\hline $\mathbf{1 0}$ & 42 & Kadın & Lisans & $\begin{array}{c}\text { Genel Müdür } \\
\text { Yardımcısı }\end{array}$ & 23 yıl \\
\hline $\mathbf{1 1}$ & 38 & Erkek & Lisans & Önbüro Müdürü & 19 yıl \\
\hline $\mathbf{1 2}$ & 41 & Erkek & Lisans & $\begin{array}{c}\text { Satıs-Pazarlama } \\
\text { Müdürü }\end{array}$ & 20 yıl \\
\hline $\mathbf{1 3}$ & 38 & Erkek & Lisans & $\begin{array}{c}\text { Satş-Pazarlama } \\
\text { Müdürü }\end{array}$ & 19 yıl \\
\hline
\end{tabular}


Görüşme yapılan kişilerin 3 'ü genel müdür, 2'si genel müdür yardımcısı, 4'ü ön büro müdürü, 4'ü de satış-pazarlama müdürü olarak görev yapmaktadır. Görüşme yapılan toplam 13 kişiden sadece 2 kişi kadın, diğerleri ise, erkektir. Bir kişi önlisans mezunu, diğerleri ise lisans düzeyinde eğitim almışlardır. İş tecrübeleri ise, 15 ile 24 yıl arasında değişmektedir.

Kültür ve Turizm Bakanlığı, 1 Temmuz 2020 tarihinde yayınladığ1 yeni genelge ile 50 oda üstü tüm otellere güvenli turizm sertifikası alma zorunluluğu getirmiştir. $\mathrm{Bu}$ doğrultuda araştırmaya katılan otel yöneticilerine ilk olarak otellerinin güvenli turizm sertifikası olup olmadığı sorulmuştur. Görüşme yapılan tarihlerde bir otel güvenli turizm sertifikası almak için başvuru yaptığını henüz denetime gelmedikleri için belgeye sahip olmadıklarını ifade etmiştir. Onun dışındaki tüm otel yöneticileri güvenli turizm sertifikasına sahip olduklarını belirtmişlerdir. Güvenli turizm sertifikasının otelinize avantajı var mı? Sertifika misafirlerin otelinize güven duyması açısından önemli mi? Sorusuna bir otel yöneticisi misafir açısından önemli olmadı̆̆ını belirtmiştir. Katılımcı 2 “Bizde konaklamaya gelen misafir bunu sorgulamiyor. Ama otelin ayda bir denetlenmesi, prosedürlerin yerine getirilmesi önemli" ifadelerini kullanırken, diğer tüm yöneticiler sertifikanın misafir açısından önemli olduğunu vurgulamışladır. Katılımcı 2 “Anlaşmalı olduğumuz acenta güvenli turizm sertifikasını kullanarak reklamımızı yapıyor, buna yönelik otelin açılışında reklam afişleri hazırlandı, tüm güvenlik önlemleri ile otelimizi kapılarını şu tarihte açıyor diye", Katılımcı 3 "Özellikle sertifika yurtdışı pazarlarda daha fazla prestij sağlıyor, yabancı misafirler buna çok önem veriyor", Katılımcı 6 "Bizim gibi çocuklu ailelere hitap eden, çocuk dostu otel misafirleri bu sertikayı daha çok sorguluyor, çocukları ile tatile çıkacakları için otele güven duymaları açısından sertifika çok önemli" ifadelerini kullanmışlardır.

Otelde COVID-19'a yönelik olarak aldığınız tedbirler nelerdir? Sorusuna tüm otellerde, otele giriş ve çıkış işlemleri sosyal mesafe kurallarına uygun olarak düzenlenerek, mesafe işaretlemeleri yerleştirildiği, otel girişlerinde temassız ateş ölçer ile misafirlerin ateş ölçümü yapılarak kayıt altına alındığı belirtilmiştir. Resort otellerde alan büyük olduğu için öncelikle güvenlik kulübesine gelen aracın içinde misafirlerin ateşlerinin ölçüldü̆̆ü, sonrasında otel binasının girişinde tekrar 
ölçüldüğgu ifade edilmiştir. Otel girişlerinde talep edilmesi halinde misafire verilmek üzere maske, eldiven gibi kişisel koruyucu malzeme hazır bulundurulduğu, oda kartlarının dezenfekte edilerek hazırlandığı, gerekli belgeleri doldurmak için kullanılacak kalemlerin dezenfekte edilerek ya da poşetlenerek misafirlere verildiği vurgulanmıştır. Katılımcı 6, oda kartlarını COVID-19 tedbirleri nedeniyle tek kullanımlık kart olarak kullandıklarını ve misafirden geri almadıklarını belirtmiştir. Katılımcı 1, 4, 11 ve 12 otelin girişinde dezenfektan paspası bulunduğunu belirtmişlerdir. Katılımcı 8 “Otelin girişinde dezenfektan paspası ve el dezenfektanı var, resepsiyonda kalemler poşetli, kullanılan kalemler dezenfekte ediliyor. Tüm restoran girişlerine el dezenfektanı konuldu. Asansör ve ofislerde kaç kişinin aynı anda bulunabileceğini belirten uyarılar var. Havuzda kullanılan havlular tek tek poşetlendi" ifadelerini kullanmıştır. Tüm otellerde misafirlere, geldikleri yer, son ziyaret ettikleri ülkeler, kendileri ile irtibata geçilebilecek adres ve telefon numaraları ile sağlık durumlarını ve işletmenin belirlediği COVID-19 aksiyon planına uyacaklarını taahhüt eden beyanname imzalatıldı̆̆ı söylenmiştir. Katılımcı 1,4,6,10 ve 13 otele giriş yapan misafirlerin valizlerinin dezenfektan makinası ile dezenfekte edilerek otele alındığını belirtmişlerdir. Diğer katılımcılar ise, dezenfektan kullanılıp bezle silinerek valizlerin otele alındığını söylemişlerdir. Bazı otel yöneticileri oda temizliğinde misafir ayrıldıktan sonra dezenfektan makinası yardımıyla odaların temizlendiğini belirtirken (Katılımcı 1, 6, 7, 10, 12), diğer otel yöneticileri (Katılımcı 2, $3,4,5,8,9,11,13)$ ise, dezenfektan makinasına sahip olmadiklarını, dezenfektan malzemeleri yardımıyla odaların temizlendiğini belirtmişlerdir. Otellere ek maliyet getirdiği için dezenfektan makinaları yerine temizlik malzemeleri tercih edildiği görüşmelerde ortaya çıkmıştır. Görüşme yapılan yöneticilerden biri henüz daha otel açılmadan güvenli turizm sertifikasını almak için otele alınan malzemelerin 60 bin TL otele masrafı olduğunu vurgulamıştır. Tüm odalarda bulunan kâğıt, karton gibi dosya malzemelerinin kaldırıldığ 1 ifade edilmiştir. Katılımcı 1, odalar temizlendikten sonra yeni misafir odaya girerken kapıya asılan, temizlendikten sonra odaya ilk defa siz giriyorsunuz, anlamında kullanılan bantlar takıldığını ifade etmiştir. Ayrıca birçok otel yöneticisi oda temizliklerinde tek kullanımlık kullan-at bezler kullanıldı̆̆ını belirtmiştir. Tüm genel alanlarda oteller sosyal mesafe kurallarına 
uygun düzenlemeler yaparak, gerekli işaretlemelerin yapıldı̆̆ını, ayrıca bilgilendirme yazıları asıldığını söylemiştir. Otellerin tüm genel alan tuvaletlerinde bulunan el kurutma makineleri kaldırılarak, tek kullanımlık kâğıt havlu yerleştirildiği vurgulanmıştır. Restoran girişlerinde ve barlarda el dezenfektasyon aparatları bulundurulduğu, yiyecek ve içecek bölümlerinde kullanılan self servis çay ve kahve makinelerinin kaldırılarak personel tarafından servis edilmesinin sağlandığı belirtilmiştir. Açık büfelerde yiyecekler teması engelleyecek cam bariyerler ile kapatıldığını ve servisin, mutfak personeli tarafından yapılması sağlandığı söylenmiştir. Çatal bıçak takımlarının tek kullanımlık ambalajlar içinde servis edilmesi sağlanarak, servis personelinin tek kullanımlık eldiven ve maske ile hizmet verdiği belirtilmiştir. Havuz ve plajlarda şezlongların, sosyal mesafe kurallarına uygun olarak düzenlenmiş olduğu belirtilmiştir. Katılımcı 1 "Havuzda kullanılan havlular tek tek poşetlendi, şezlonglar kirli ve temiz diye uyarıcı levhalarla ayrıldı. Eğer herhangi bir misafir şezlongu kullandıysa ve henüz dezenfekte edilmediyse üzerine kırmızı yazı ile kirli olduğunu belirten uyarı, temiz ise de yeşil renkli uyarıcı yerleştiriliyor" vurgusunu yapmıştır. Otellerde bulunan spa ve fitness salonları içinde her kullanımdan sonra dezenfektasyon işlemleri yapıldı ğı ve aynı anda kullanacak kişi sayılarının sınırlandırıldığı belirtilmiştir.

COVİ-19 öncesi geçen sezon hangi pazarlara hitap ediyordunuz? COVID-19 sonrası hangi pazarlara yöneldiniz? Sorusuna otel yöneticilerinin çoğunluğu seyahat kısıtlamalarından dolayı iç pazara yöneldiklerini belirtmişlerdir. Katılımcı 1, "Yoğun olarak Uzakdoğu pazarına hitap eden bir oteldik, COVİD-19 sonrası Avrupa ve iç pazara yönelmek zorunda kaldık", Katılımcı 4," İngiltere pazarına yönelmek için Jet2 Acentesi ile bağlantıya geçtik, otelimize denetime geldiler, maalesef otel binamız eski, odaların bulunduğu koridorlar da çok uzun olduğu için yangın çıkışlarına uzak olması gerekçesiyle denetimden geçemedik, iç pazar ve Bulgaristan pazarına yöneldik", Katılımcı 7, "COVID-19 öncesi Hollanda, Belçika ve Uzakdoğu pazarı vardı. Şu anda ise, uçuş kısıtlamalarından dolayı iş için gelip otelimizde konaklayan Alman mühendisler var, ayrıca Almanya'da yaşayan Türkler var", Katılımcı 9, “COVİ-19 öncesi, Kuzeybatı Avrupa pazarı vardı, Hollanda, Belçika, Almanya, şu anda ise Türkler var. İç pazara yöneldik. Ayrıca Bulgaristan, Ukrayna, Belarus 
pazarına da yöneldik", Katılımc1 13, “COVİD-19 öncesi ilk sırada Almanya, sonra Rusya ve iç pazar yer alıyordu. COVID-19 sonrası ise, ilk sırada iç pazar, sonrasında seyahat kısıtlaması olmayan pazarlar ve Ukrayna, Belarus pazarı, gurbetçi olarak nitelendirdiğimiz yurtdışında yaşayan Türklerin olduğu pazarlara yöneldik" ifadeleri kullanılmıştır. Yöneticilerin ifadelerine göre birçok otel seyahat kısıtlamalarından dolayı iç pazara yoğunluk vermiş, ayrıca Türkiye'ye kara yolu ile geçişin daha kolay olabileceği Bulgaristan, Ukrayna gibi pazarlara yönelmişlerdir. Görüşme yapılan bazı yöneticiler Almanya, İngiltere gibi birçok ülkeden seyahat kısıtlaması olmamasına rağmen COVID-19 gerekçesiyle birçok turistin Türkiye' de tatil yapmayı tercih etmediğini belirtmişlerdir.

COVİD-19 sonrası satış-pazarlama stratejilerinizde değişiklik oldu mu? $\mathrm{Bu}$ dönemde reklam ve tanıtım için neler yapıyorsunuz? Sorusuna Katılımcı 3 "Ets tek yetkili acentamız, yaptığı reklamlarla Kuşadası otellerinde ilk 3'de çıkıyoruz, ayrıca sosyal medya hesaplarında yoğun reklam yapıyoruz. Otelimizin güvenli olduğunu vurgulayan paylaşımlar yapıyoruz", Katılımcı 4, "Yakala co. web sayfasına reklam veriyoruz, misafirlerin fırsat yakalayarak bizi tercih etmesini sağlıyoruz, ayrıca günlük tesis kullanımı için de reklamlar veriyoruz", Katılımcı 9, “Tesisin günlük kullanım sayısını artırmak için uygun fiyatlı menüler oluşturduk, bunların reklamını sosyal medya hesaplarında yapıyoruz, özellikle bu dönemde reklam ve tanıtım için sosyal medyaya yöneldik", Katılımcı 10, “Dijital pazarlamaya yöneldik, study\&holiday, work\&holiday başlıkları altında Instagram ve Facebook'ta reklam yapıyoruz, COVID-19 döneminde ortaya çıkan evden çalışma stratejisini kullanarak, otelde konakla, hem tatil yap, hem çalış reklamları yapıyoruz. Buna yönelik otelimizde çalışma odaları yaptık, birkaç özel ofis tasarladık, hızlı internet bağlantısı, bilgisayar, projeksiyon cihazı, yazıcı, faks vb. gerekli ekipmanın bulunduğu düzenlemeler yaptık", Katılımcı 12, “Otelimizin güvenli olduğunu vurgulayan, aldığımız tedbirleri anlatan videolar çektik, videolar hem İngilizce hem de Türkçe olarak sosyal medya kanallarında, web sayfamızda paylaşıldı" ifadelerini belirtmiştir. COVID-19 sonrası oteller yoğun olarak dijital pazarlamaya yönelmiş, sosyal medya hesaplarını aktif olarak kullanmaya başlamışlardır. Özellikle geniş 
kitlelere en kolay ve hızlı ulaşım araçlarından olan sosyal medya COVID-19 döneminde diğer tanıtım araçlarına göre öne çıkmıştır.

COVID-19 sonrası fiyatlandırma stratejileriniz hakkında bilgi verir misiniz? Sorusuna tüm yöneticiler fiyatların düştüğü yönünde yanıt vermiştir. Katılımcı 1, “\%40’a kadar düşüş yaşadık”, Katılımcı 2, “dış pazarda \%10, iç pazarda \%20 düşüş oldu”, Katılımcı 3, “\%50 gibi yüksek bir oranda düşüş var”, Katılımc1 5, "iç pazarda \%30 düşüş oldu", Katılımcı 8, "iç pazarda \%15 gibi, dış pazarda ise \%40 gibi bir düşüş oldu”, Katılımcı 10, “iç pazarda \%12 düşüş var”. COVİD-19 sonrası oteller yeniden misafirler tarafından tercih edilmek ve rekabet pazarından pay alabilmek için fiyat indirimlerine gitmişlerdir. Özellikle mesafe olarak yakın konumlandırmaları olan ve aynı konseptte hizmet veren oteller birbirleriyle rekabete edebilmek ve tercih edilebilmek için yoğun indirimler uygulamaktadırlar.

COVID-19 sonrası dijitalleşme konusunda yaptığınız çalışmalar var mı? Eğer varsa otelinizin tanıtım ve pazarlamasına etkileri nelerdir? Sorusuna yöneticilerin hepsi daha az temas gerektiren uygulamaların otellerde ön plana çıktığı ve öneminin COVID-19 sonrası daha iyi anlaşıldığı yanıtını vermişlerdir. Bu uygulamaların da misafirler tarafından tercih edildiği ve pazarlama aracı olarak kullanıldığı vurgusu yapılmıştır. Katılımcı 1, “Otelimize ait üyelik programı misafirler tarafından daha çok tercih ediliyor, özellikle temassız check in için yoğun olarak kullanılıyor", Katılımcı 2, “Otelde bulunan tüm kağıt menüler kaldırıldı, QR kod uygulaması ile misafirler cep telefonlarından barkod okuyucu ile menülere ulaşıyorlar, ayrıca restoranlarda yiyecek büfelerinde bulunan her yiyeceğe yine barkod okuyuculu ile etiketler yerleştirdik, etiketler üzerinde, Türkçe, İngilizce, Almanca ve İspanyolca olarak ürünlerin isimleri yer almakta, kalori değerleri, alerjen bilgileri bulunmaktadır. Barkod okutulduğunda ise, ürünün içinde bulunanlar, alerjenler ve protein, yă̆ ve karbonhidrat değerleri açıllayıcı bir şekilde yer almaktadır", Katılımc1 4, "Resepsiyon önüne yerleştirdiğimiz QR kod okuyucu ile tüm misafirler COVİD-19 ile ilgili otelimizde aldığımız tüm tedbirlere ulaşabiliyorlar, yazılı olarak vermek yerine bu daha dikkat çekici ve güvenli bir yöntem oldu", Katılımc1 7, “Uluslar arası standartlarda kullanılan sadakat programımızın üye sayısı arttı, program üyelerine dijital check in, check out, oda servisi gibi konularda büyük 
kolaylık sağladığı için otelin tercih edilmesini destekliyor”, Katılımcı 11, "COVID-19 sonrası dijital aplikasyon için çalışmalara başladık, artık bu konunun tün dünyada otelcilik sektöründe önemi anlaşıldığı için bir yazılım firması ile bağlantıya geçerek 2021 sezonunda kullanılmak üzere temassız check in, check out yapılabilecek, oda servisleri konusunda destek verecek, taksi çağırma, spa randevusu oluşturma gibi birçok konuda kolaylık sağlayacak bir uygulama hazırlıyoruz" ifadelerini kullanmışlardır. Otellerin gelecek yıllarda daha fazla dijital uygulamalar kullanacağı, bunun için alt yapı oluşturmaya başladıkları, beklentilerin bu yönde olduğu ortaya çıkmıştır. Büyük bütçeler gerektiren dijitalleşme uygulamaları otellerin öncelikleri arasında yer alacaktır. Özellikle daha az temas gerektiren, kâğıt, kalem gibi malzemelerin daha az kullanılacağı uygulamalara eğilim artmaktadır.

Misafirlerin COVID-19 sonrası otelden beklentileri nelerdir? Misafirlerin istekleri neler olmuştur? Sorusuna tüm yöneticiler otellerin kapalı olduğu dönemde rezervasyonlarla ilgili çok soru geldiğini, buna yönelik olarak da koşulsuz ücret iadesi yaptıklarını, dileyen misafirler için ücretsiz tarih erteleme yaptıklarını belirtmişlerdir. Misafirlerin bu dönemde beklentilerinin öncelikli olarak hijyen ve güvenli tatil olduğunu ifade etmişlerdir.

COVID-19 sonrasinda butik otel tercih etme, villa kiralama, tekne kiralama gibi tatil alternatifleri öne çıktı. Siz bu rekabet pazarlarına yönelik olarak neler yaptınız? Sorusuna Katılımcı 1, "Günlük, haftalık olarak tercih edilebilecek 1+1, 2+1, 3+1 suite daireleri tasarladık, kalabalık restoranlarda, büyük otellerde tatil yapmayı tercih etmeyen misafirlere, ev rahatlığında, izole tatil seçeneği sunduk. Özellikle yurtdışında yaşayan Türkler tarafından yoğun talep gördü”, Katılımcı 3, "Villa ya da tekne kiralama maliyetleri çok yüksek olduğu için her şey dahil hizmet veren otelimiz sunduğu fiyat avantajıyla rekabet ediyor, tatile çok büyük paralar harcamak istemeyen misafirler bizi tercih ediyor, zaten güvenli turizm sertifikası ile alınan tedbirlere ilişkin bilgilendirmeyi yaptığımız için sorun olmuyor”, Katılımcı 5, “Otel odalarımız dışında COVID-19 öncesi pek de tercih edilmeyen 5 adet villamız vardı, şu anda onlara yoğun talep var, biz de onları pazarlamak için airbnb ile çalışıyoruz, günlüğü 7-8 bin tl'ye kiralıyoruz”, Katılımcı 11, “Otelimize ait çiftlik alanına taş evlerden konaklama imkanı sunma projesi bu dönemde ortaya çıktı. 2021 sezonu için 
çiftlik alanına 6-7 tane taş ev yaparak, gelen misafirlerin organik ürün yetiştirme, at binme, biniş dersi alma, tüm yiyecekleri organik olarak tüketme gibi seçenekleri sunacağı. Kırsal turizme de yönelerek COVID-19 sonrası değişen tüketici tercihlerine hitap etmeyi amaçliyoruz".

COVİD-19 sonrası bu yılı kurtarmak için otelinize yeterli talep olacağını düşünüyor musunuz? Sorusuna hemen hemen tüm yöneticiler çok büyük bir beklentileri olmadığını, zarar etmeden oteli kapatıp sezonu kurtarmak istediklerini belirtmişlerdir.

COVİD-19 sonrası Türkiye'de ki otelcilik anlayışında nasıl bir değişiklik olur? Sorusuna yöneticilerin çoğunluğu güvenlik ve hijyen konularında alınan tedbirlerin süreklilik arz etmesi gerektiğini belirtmişlerdir. Katılımcı 2, "Açık büfelerde aldığımız tedbirler sayesinde yiyeceklerde \%50 oranında tasarruf sağladık, misafirler kendileri aldıklarında çok fazla yiyecek ziyan oluyordu, mutfak personelinin servis etmesi bunun önüne geçti, bu şekilde kalmalı", Katılımcı 8, “Açık büfelerde personel yükü arttı, her büfede yemek servisi verecek personel ihtiyacı doğdu, misafirler de kendileri istedikleri kadar yemek almak istiyor, bu durum ne kadar devam eder bilemiyorum" , Katılımc1 13, “Oda-kahvaltı olarak hizmet veren bir oteliz, COVID-19 sonrası açık büfe kahvaltıyı kaldırdık, misafirlerin önüne kapalı şekilde sunulan serpme kahvaltı veriyoruz, bu konuda çok şikayet alıyoruz, eskisi gibi açık büfe istiyorlar, belki ileride bu durum eski haline döner" yanıtlarını vermişlerdir. Yöneticilerden alınan yanıtlar doğrultusunda, şu anda hizmet veren tüm otellerin COVİD-19 sonrası yapılan yeni uygulamalara uyum sağlamaya çalıştıkları, yüksek doluluk oranlarında uygulamaların nasıl devamlılı̆̆ı konusunda endişelerinin olduğu ortaya çıkmıştır. Özellikle restoranlarda yemek büfelerinde personelin servis yapması, misafir sayısı fazla olduğunda hem uzun kuyruklara ve bekleme sürelerine sebep olacak hem de yabanc1 dil bilgisi iyi olmayan personelin yabanc1 misafirle anlaşmazlık yaşamasına sebebiyet verebilecektir. $\mathrm{Bu}$ da otellere müşteri memnuniyetsizliği ve şikâyet olarak geri dönebilir.

Son olarak sorulan "COVID-19 salgını sonrası turizmde toparlanma için neler yapılmalı?" sorusuna yöneticilerin çoğunluğu; hükümetlerin planlama yapması 
gerektiği, sektör paydaşlarının ortak hareket ederek yeni projeler üretmesinin gerekliliği ve tanıtım için daha etkili çalışmalar yapılmasının gerekli olduğu yönünde yanıtlar vermişlerdir.

\section{SONUÇ VE ÖNERİLER}

COVİ-19 salgınından en çok etkilenen sektörlerin başında turizm gelmiştir. 2019 yılında Türkiye 45,1 milyon ziyaretçi ağırlamıştır. 2020 y1lı için öngörülen rakamlar çok daha yüksek olmasına rağmen tüm dünyayı etkisi altına alan COVİD19 salgını sonrası 2020 Mart ayında Türkiye' yi ziyaret eden yabancı sayısı bir önceki yıla göre \%67,83 azalış göstermiştir. 2020 yılı Nisan ve Mayıs aylarında ise, bir önceki yıla göre \%99,26'lık bir azalış göstererek durumun ciddiyeti ortaya çıkmıştır. Salgın nedeniyle uygulanan seyahat yasakları, sınır kapılarının kapatılması gibi kisitlamalar, ayrica 23 Nisan, 19 Mayıs ve Ramazan Bayramı tatillerinde uygulanan dörder günlük sokağa çıkma yasakları ile 31 ilde uygulanan giriş-çıkış kısıtlamaları, otellerin doluluk oranlarının düşmesine neden olmuştur. Normalleşme sürecinin başladığı 2020 Haziran ayı itibariyle oteller aldıkları tedbirler ile yeniden faaliyete geçmeye başlamışlardır.

Kültür ve Turizm Bakanlığı öncülüğünde oluşturulan “Güvenli Turizm Sertifikasyon Programı" ile oteller yeniden düzenlemelere gitmişlerdir. Misafirin otele girişi ile başlayan bu uygulamalar, personel için alınacak önlemler, otellerin genel alanlarında yapılacak düzenlemeler (yatak odaları, mutfaklar, yeme-içme üniteleri, yüzme havuzları ve plajlar, fitness salonları-spa, animasyon salonları, mini kulüp), otel taşıtları ile ilgili uygulanması gereken tedbirler, acil durum ile ilgili yapılacakları kapsayan çok geniş bir yelpazede uygulamaya konulmuştur. Bu tedbirler altında faaliyetlerine devam eden otel işletmeleri satış ve pazarlama stratejilerini de COVID-19 sonrası değiştirmişlerdir. COVİD-19 salgını otel işletmelerini daha dikkatli ve bilinçli olmaya teşvik etmiştir. Salgın sonrası misafir beklentileri de bu yönde değişmiştir. Misafirlerin özellikle hijyen ve alınan tedbirler konusunda konaklayacakları otelden beklentileri yüksektir.

COVİD-19 sonrası alınan tedbirlerle faaliyete geçen Kuşadası'ndaki 5 yıldızlı otellerin hepsi güvenlik turizm sertifikası için başvuru yapmış ve denetim bekleyen 
bir otel hariç hepsi belgeyi almışlardır. Sertifikanın misafirin otele güven duyması ve ayrıca otelin reklamının daha etkili yapılması açısından önemli olduğu anlaşılmıştır.

COVİD-19 sonrası otelcilik sektöründe temassız işlemlerin artacağı, dijitalleşme konusunda Seyahat kısıtlamalarından dolayı özellikle Avrupa pazarından misafir kaybı olan birçok otel iç pazara yönelmiş ya da uçuşların serbest olduğu ülke pazarlarına yönelik pazarlama çalışmaları başlatmışlardır. Satış ve pazarlama stratejilerinin de COVID-19 sonrası misafir beklentilerine göre şekillendiğini belirten otel yöneticileri özellikle sosyal medya reklamlarına yoğunluk verdiklerini, otellerinde aldıkları tedbirleri de içeren tanıtımlar yaptıklarını, güvenli turizm belgesinin de iyi bir güven ve pazarlama aracı olduğunu ifade etmişlerdir. Ortaya çıkan bu sonuç daha önce yapılan Kıvılcım (2020), Chang vd. (2020) ve Wen vd. (2020) ile benzerlik göstermektedir. Otellere ekstra maliyet yükleyecek bu yeni akıllı sistemler, uzun vadede misafir beklentilerini daha iyi karşılayarak, misafir memnuniyetini artıracaktır. Uygulamaya konulacak bu yenilikler pazarlama arac1 olarak da otellerde kullanılacaktır.

COVID-19 sonrası otel fiyatlarının hem iç hem de dış pazarda düşmesi ciddi bir ekonomik kayba neden olmuştur. Ortaya çıkan bu sonuç Acar (2020), Bahar \& İlal (2020), Bakar \& Rosbi (20020), Gössling, Scott \& Hall (2020), Karim, Haque, Anis \& Ulfy (2020) çalışmalarında turizm ve otelcilik sektörünün çok büyük gelir kaybına uğradığı yönünde ortaya çıkan sonuçla paralellik göstermektedir.

Aydın ve Doğan (2020), Demir, Günaydın ve Demir (2020), Demir ve Türkmen (2020), Tanrıkılu (2020), Yenişehirlioğlu, ve Salha (2020), Chang, McAleer ve Ramos (2020), Wen, Kozak, Yang ve Liu (2020) çalışmalarında ortaya çıan kalabalık turizm tesisleri yerine kişiye özel hizmetlerin sunulduğu daha küçük tesislerin öne çıktığı, villa, yat kiralama gibi alternatiflere yönelmenin olduğu, yeni turizm biçimlerinin turizme yön vereceği sonucu görüşme yapılan otel yöneticilerinin de bu rekabet pazarına yönelik olarak stratejiler geliştirdiği ortaya çıkmıştır. Günlük, haftalık olarak kiralanacak, içlerinde mutfak ve her türlü yemek yapma araç gereçlerinin olduğu 1+1, 2+1, 3+1 suite daireler, otel alanı içinde kiralanabilecek villa alternatifleri, kırsal turizme yönelik olarak çiftlik evleri görüşme 
yapılan otel yöneticilerinin yeni satış ve pazarlama stratejileri arasında yer almaktadır.

COVİD-19 sonrası yeniden faaliyete geçen otellerin yöneticilerinin çoğunluğunun 2020 yılı için çok büyük beklentilerinin olmadığı, bu yılı zarar etmeden, düşük bir kârla kapatmayı hedefledikleri ortaya çıkan diğer bir sonuçtur. COVID-19 salgını sonrası turizmde toparlanma için hükümetlerin planlama yapması gerektiği, sektör paydaşlarının ortak hareket ederek projeler üretmesinin gerekliliği ve reklam, tanıtım için daha etkili, dikkat çekici çalışmalar yapılması gerektiği sonucu Atay (2020), Demir vd. (2020), Bakar ve Rosbi (2020), Gössling vd. (2020), Khadka vd. (2020 Ranasinghe vd. (2020) ile benzerlik göstermektedir.

Yapılan görüşmeler sonucunda otellerin COVİD-19 sonrası ciddi ekonomik kayıplara uğradıkları, yeniden toparlanma ve müşteri elde etmek için satış, pazarlama stratejilerini COVID-19 sonrası alınan tedbirleri vurgulayacak şekilde değiştirdikleri, uçuşların serbest olduğu ülkelere yöneldikleri, o ülkelerin seyahat acentalarıyla bağlantıya geçtikleri, daha az temas gerektiren uygulamalara, akıllı telefon aplikasyonlarına, QR kod okuyucularla yapilan menü düzenlemelerine geçtikleri belirlenmiştir.

COVİD-19 sonrası otel işletmelerine yapılacak öneriler şu şekilde özetlenebilir:

-Misafirlerin temel beklentisi olan hijyen ve alınan tedbirler konusundaki kriterlerin devamlılığı sağlanmalı, bu konuya özen gösterilmelidir.

-Otel işletmelerinin daha az temas gerektiren akıllı uygulamalara yönelmesi gerekmektedir. Online check-in, check-out, akıllı telefonla oda siparişi verme, QR kod okuyucularla menü ve diğer bilgilendirmelere ulaşma, oda kartı yerine barkod okuyucularla odaya girme gibi seçeneklerin artırılması gerekmektedir. Dijitalleşmenin önemi iyice anlaşılmalı ve buna bütçe ayrılmalıdır.

-Sosyal medyanın daha aktif bir şekilde kullanılması sağlanmalıdır. Özellikle sosyal medya pazarlamasının misafir geri dönüşleri açısından en etkili yol olduğu unutulmamalıdır. Profesyonel ekipler tarafından sosyal medya hesapları yönetilmelidir. 
-Ülke tanıtımında sektör paydaşlarının bir araya gelerek daha etkili tanıtım atakları gerçekleştirmesi sağlanmalıdır. Türkiye'de sağlık ve güvenlik konularında daha olumlu imaj yaratmak için de çalışmalar yapılması gerekmektedir.

-COVID-19 sonrası otellerde konaklayan misafirlerin memnuniyetinin sağlanması ile ilgili olarak her otelin bu konuya hassasiyetle özen göstermesi gerekmektedir. Özellikle bu dönemde misafir beklentilerinin çok iyi anlaşılması ve bu yönde çözüm odaklı çalışmalar yapılması sağlanmalıdır.

COVİ-19 salgın döneminde otellerin pazarlama stratejilerinin araştırıldığı bu çalışmanın Kuşadası destinasyonun da yapılması ve sadece 5 yıldızlı otelleri kapsaması araştırmanın kısıtları arasındadır. Aynı çalışma farklı destinasyonlarda tekrarlanabilir. COVID-19 sonrası otellerde konaklayan misafirlerin memnuniyetleri nicel ve nitel araştırma yöntemleri kullanılarak ölçülebilir. Sektördeki diğer paydaşlarla da görüşmeler yapılarak pazarlama çalışmaları hakkında bilgi toplanabilir. 


\section{KAYNAKÇA}

Acar, Y. (2020). Yeni Koronavirüs (COVID-19) Salgını ve Turizm Faaliyetlerine Etkisi, Güncel Turizm Araştırmaları Dergisi, 4(1), 7-21.

Altunışık, R., Coşkun, R., Bayraktaroğlu, S. ve Yıldırım, E. (2010). Sosyal Bilimlerde Araştırma Yöntemleri: SPSS Uygulamalı, Sakarya Yayıncılık.

Atay, L. (2020). COVID-19 Salgını ve Turizme Etkileri. Seyahat ve Otel İşletmeciliği Dergisi, 17(1), 168172.

Aydın, B. ve Doğan, M. (2020). Yeni Koronavirüs (COVID-19) Pandemisinin Turistik Tüketici Davranışları ve Türkiye Turizmi Üzerindeki Etkilerinin Değerlendirilmesi, Pazarlama Teorisi ve Uygulamaları Dergisi, 6 (1), 93-115.

Aydın İl Kültür ve Turizm Müdürlüğü (2020). https://aydin.ktb.gov.tr/TR-177012/turizmtesisleri.html.

Bahar, O. ve Çelik İlal, N. (2020). Coronavirüsün (COVID-19) Turizm Sektörü Üzerindeki Ekonomik Etkileri, The, International Journal of Social Sciences and Education Research, 6(1), 125-139.

Bakar, N. A. ve Rosbi, S. (2020). Effect of Coronavirus Disease (COVID-19) to Tourism Industry, International Journal of Advanced Engineering Research and Science, 7(4), 189-193.

Chang, C.L. , McAleer, M. ve Ramos, V. (2020). A Charter for Sustainable Tourism after COVID-19. Sustainability 12(9), 3671.

Dasgupta, D. (2011). Tourism Marketing. London: Pearson, p. 75.

Demir M., Günaydın Y. ve Demir Ş. (2020). Koronavirüs (COVID-19) salgınının Türkiye'de Turizm Üzerindeki Öncülleri, Etkileri ve Sonuçlarının Değerlendirilmesi, International Journal of Social Sciences and Education Research, 6(1), 80-107.

Demir, B. ve Türkmen, S. (2020). COVID-19 Salgının Oluşturduğu Sağlık Riski Sonrasında Türk Turistlerin Tatil Beklentilerinin Belirlenmesi, Türk Turizm Araştırmaları Dergisi, 4(3), 2456-2471.

Doğancılı, O. (2020). COVID-19 Salgını Sonrası Turizm Destekleri, Türk Turizm Araştırmaları Dergisi, 4(3): 2808-2820.

Ekstein, N. (2020). The Coronavirus's Effect on Tourism Will Carry Into 2021, Experts Say. Erişim Adresi: $\quad$ https://www.bloomberg.com/news/articles/2020-02-13/coronavirus-s-effect-ontourismwill-carry-into-2021-experts-say.

Eryılmaz, B. (2020). Türkiye' de Faaliyet Gösteren Otel Zincirlerinin Yeni Tip Koronavirüs (COVID-19) Bilgilendirmeleri, Turizm Akademik Dergisi, 7 (1), 15-27. 
Gössling, S., Scott, D. ve Hall, C. M. (2020). Pandemics, tourism and global change: A rapid assessment of COVID-19. Journal of Sustainable Tourism, 1-20.

Gürbüz, S. ve Şahin, F. (2014). Sosyal Bilimlerde Araştırma Yöntemleri. Ankara: Seçkin Yayıncllık.

Hoque, A., Shikha, F. A., Hasanat,M. W., Arif,I. ve Abdul Hamid, A.B. (2020). The Effect of Coronavirus (COVID-19) in the Tourism Industry in China, Asian Journal of Multidisciplinary Studies, 3(1), 52-58.

İbiş, S. (2020). COVID-19 Salgınının Seyahat Acentaları Üzerine Etkisi, Safran Kültür ve Turizm Araştırmaları Dergisi, 3(1): 85-98.

Karim, W., Haque, A., Anis, Z. ve Ulfy, M. A. (2020). The Movement Control Order (MCO) for COVID-19 Crisis and its Impact on Tourism and Hospitality Sector in Malaysia. International Tourism and Hospitality Journal, 3(2), 1-7.

Khadka, D., Pokhrel, G. P., Thakur, M. S., Magar, P. R., Bhatta, S., Dhamala, M. K. ve Bhuju, D.R. (2020). Impact of COVID-19 on the Tourism Industry in Nepal. Asian Journal of Arts, Humanities and Social Studies, 3(1), 40-48.

Kıvılcım, B. (2020). COVID-19 (Yeni Koronavirüs) Salgınının Turizm Sektörüne Muhtemel Etkileri. USOBED Uluslararası Batı Karadeniz Sosyal ve Beşeri Bilimler Dergisi, 4(1), 17-27.

Lee, C. C., ve Chen, C. J. (2011). The reaction of elderly Asian tourists to avian influenza and SARS, Tourism Management, 32(6), 1421-1422.

McKinsey (2020). Hitting the Road again: How Chinese Travelers are Thinking about Their First Trip after COVID-19. https://www.mckinsey.com/featured-insights/asia-pacific/hitting-the-road-againhow-chinese-travelers-are-thinking-about-their-first-trip-after-COVID-19?cid=other-eml-alt-mbl

Özdemir- Altınay, M. (2020). Covıd-19 Salgını Sonrası Alınan Önlemlerle Turizm: Muhtemel Senaryolar. Journal of Recreation and Tourism Research, 7 (2), 222-238.

Ranasinghe, R., Damunupola, A., Wijesundara, S., Karunarathna, C., Nawarathna, D., Gamage, S., Ranaweera, A. ve Idroos, A. A. (2020). Tourism After Corona: Impacts of Covid 19 Pandemic and Way Forward for Tourısm, Hotel And Mice Industry in Sr1 Lanka, p.1-19, SSRN: https://ssrn.com/abstract $=3587170$.

Sağlık Bakanlığı. (2020). Erişim Adresi: https:// covid19.saglik.gov.tr/

STR (2020) COVID-19: Hotel Industry Impact, https://str.com/data-insights-blog/coronavirus-hotelindustry-data-news.

Sheresheva, M. Y. (2020). Coronavirus and Tourism, Population and Economics, 4(2), 72-76.

Şanlı C., Erdem A. ve Unur K. (2020). Koronavirüs Salgınının Tatile Çıkma Niyeti Üzerine Etkisi, Türk Turizm Araştırmaları Dergisi, 4(3), 1671-1688. 
Tanrıkulu M. (2020). COVİD-19 Gölgesinde Türkiye'de Holistik Turizm ve Kültüre Dönüş, Avrasya Sosyal ve Ekonomi Araştırmaları Dergisi, 7 (5), 406-417.

Türkiye Tanıtım ve Geliştirme Ajansı (2020). Güveli Turizm Sertifikasyon Kriterleri, https://tga.gov.tr/wp-content/uploads/2020/07/Konaklama-TR-13.07.20_v1.pdf

Türkiye Turizm Tanıtım ve Geliştirme Ajansı (2020). https://www.tga.gov.tr/turkiyenin-guvenliturizm-programi-hakkinda/.

TÜROB (2020) Türob Sektör Raporları, http://www.turob.com/tr/yayinlar--raporlar/turobraporlari/turob-sektor-raporlari.

UNWTO (2020). Interntional Tourist Numbers Could Fall 60-80 \% in 2020,

UNWTO Reports. https://www.unwto.org/news/COVID-19-international-tourist-numbers-couldfall-60-80-in-2020. Erişim Tarihi: 01.07.2020.

Wen, J., Kozak, M., Yang, S. ve Liu, F. (2020). COViD-19: Potential Effects on Chinese Citizens' Lifestyle and Travel. Tourism Review. doi: 10,1108/TR-03-2020-0110.

Wilson, M.E. ve Chen, L. H. (2020). Travelers Give Wings to Novel Coronavirus (2019-Ncov). Journal of Travel Medicine, 27(2): 1-3.

Worldometer (2020) Erişim Adresi: https://www.worldometers.info/coronavirus/\#countries

Yatırım ve İşletmeler Genel Müdürlüğü (2020). Kültür ve Turizm Bakanlığı, Turizm İstatistikleri, https://yigm.ktb.gov.tr/TR-9851/turizm-istatistikleri.html.

Yatırım ve İşletmeler Genel Müdürlüğü (2020). Kültür ve Turizm Bakanlığı, Konaklama İstatistikleri, https://yigm.ktb.gov.tr/tesis-konaklama-istatistikleri).

Yenişehirlioğlu E. ve Salha H. (2020). Covid 19 Pandemisinin Türkiye İç Turizmine Yansımaları: Değişen Talep Üzerine Bir Araştırma, İstanbul Ticaret Üniversitesi Sosyal Bilimler Dergisi COVID-19 Sosyal Bilimler Özel Sayısı, 19 (37), 355-368.

Yıldırım, A. ve Şimşek, H. (2006). Sosyal Bilimlerde Nitel Araştırma Yöntemleri, Ankara: Seçkin Yayınları. 


\section{ETIKK KURUL İZINN BELGESI}

T.C.

ADNAN MENDERES ÜNIVERSITESİ REKTÖRLÜĞÜ

SOSYAL VE BEŞERI BILIMLER ARAŞTIRMALARI

ETÍK KURULU

SAYI: $31906847 / 050.04 .04-08 / 15$

AYDIN

KONU: Başvurunuzun değerlendirilmesi

$22 / 072020$

Sayın Dr. Öğr. Üyesi Ahu YAZICI AYYILDIZ

Turizm İșletmeçiliği Öğrt. Üyesi.

Adnan Menderes Üniversitesi Sosyal ve Beșeri Bilimler Araștırmaları Etik Kurulu'nun 22/07/2020 tarihinde yapılan olağan toplantısında çalışmanızla ilgili alınan 06 nolu karar aşağıda sunulmuştur.

Bilgilerinize sunarım.

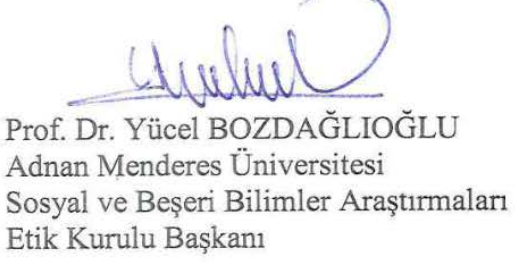

\section{KARAR-}

Protokol No :..................

Sorumlu Yürütücüi Dr. Öğr. Üyesi Ahu YAZICI AYYILDIZ Turizm İșletmeçiliği Öğrt. Üyesi.

Adnan Menderes Üniversitesi Sosyal ve Beșeri Bilimler Araștırmalanı Etik Kurulu'nca 22/07/2020 tarihinde onay verilen; Aydın Adnan Menderes Üniversitesi Turizm İşletmeciliği ABD.Öğrt.Üyesi Dr.Öğrt.Üyesi Ahu YAZICI AYYILDIZ'ın yürütücülüğünü yapmış olduğu "Covid-19 Salgın Döneminde Otellerin Pazarlama Strateiileri: Kușadası Örneğii" başliklı çalışmaya ait 17/07/2020 tarihli başvuru dilekçesi görüşüldü.

Çalıșmanın Etik Kurul Uygunluk Onayını almasına oy birliği ile karar verilmiştir. 